\title{
Coração outsider
}

\section{Edélcio Mostaço}

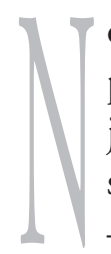

o acanhado panorama teatral de Florianópolis um projeto levado a cabo por dois jovens artistas se destaca: quase sem recursos financeiros, sem o apoio de incentivos - como, de resto, a restante produção estadual - eles apostaram no talento e na invenção. Jefferson Bittencourt encena e Renato Turnes interpreta Trilogia Lugosi, um tríptico dedicado ao terror. A idéia é a construção de três espetáculos abordando esse universo, tido como mofado e sem empuxo para gerar bom teatro. Nada mais equivocado.

A primeira realização estreou em 2003, com O Coração Delator, um conto de Edgar Alan Poe sobre o qual foram aplicados poemas e outros escritos, na tessitura de um roteiro bastante curioso e não-previsível para quem conhece o original.

Em 2005 surgiu Outsider, dessa vez tomando uma narrativa de H. P. Lovecraft como dramaturgia, oferecendo uma nova faceta daquelas paisagens ambíguas e soturnas, povoadas por morcegos e aranhas, onde a luz de velas ilumina o farfalhar de ratos deambulando na escuridão. $\mathrm{O}$ protagonista é um morto-vivo que, saindo de sua tumba num remoto porão, intenta alcançar o alto da torre onde foi depositado. Sua meta é descobrir quem é, escalando a torre em busca de si mesmo.
O próximo passo será empreendido com O Fantástico Homem que Imita a Si Mesmo, texto especialmente escrito por Fernando Bonassi para o grupo, interessado agora em investigar temas contemporâneos e causas de angústias atuais. A montagem estreará no início de 2008, operando dessa vez um exercício metalingüístico que recorre ao instrumental multimídia, com televisores e alto-falantes no palco, corporificando em imagens e sons os vários duplos que acometem um ator-narrador antes de entrar em cena. A partir das matrizes estéticas antes empregadas, também aqui o recurso à narração direta, voltada à platéia, se incumbirá de aproximar em tom confessional a trajetória existencial embutida na ficção.

O projeto se utiliza do Teatro Armação, uma antiga residência no coração da praça XV, centro histórico da capital, local inadequado para espetáculos, mas que, graças a uma reforma, foi transformado num longo corredor acomodando a platéia e o palco, sem laterais. Um pouco lúgubre, o espaço serve como uma luva para a proposta desses artistas.

A Trilogia Lugosi parte, antes de tudo, das potencialidades contidas no trabalho do ator, inspirada, é claro, pelo mito de Bela Lugosi, o ator húngaro que Hollywood celebrizou com as criaçōes de Drácula e Frankenstein. O recurso

Edélcio Mostaço é professor do Instituto de Artes e do Programa de Pós-Graduação em Artes da UDESC. 
aos contos viabilizou um percurso bastante profícuo, destacando o intérprete como articulador da cena. Embora as raízes desse tipo de interpretação remontem aos primórdios, localizáveis na postura do rapsodo, que atravessou o medievo sob o manto de jogral e menestrel, foi junto à cultura popular pós-Renascença que encontrou seus grandes êmulos: os contistas ou contadores de histórias.

Foi essa tradição que catapultou o conto para o terreno da escrita literária; embora desde há muito tenha ela se estabilizado como tradição escrita e encontrado, com ênfase após o Romantismo, amplo campo para desenvolvimento. Na categoria do conto maravilhoso o fantástico sobressai, albergando o terror como subgênero destacado. Nele, não apenas as ações vão conhecer múltiplas facetas do maravilhoso - a força da magia, os atributos de seres encantados, os prodígios, os feitos extraordinários -, assim como os espaços que os albergam: castelos em ruínas, masmorras e edifícios soturnos, pântanos e bosques ameaçadores, cemitérios e sebes cheios de perigos, urdindo criaturas que, à vontade em tais ambientes, os exploram à larga.

Edgar Alan Poe, além de festejado contista e poeta foi também crítico e teórico. Legounos ao menos duas finíssimas análises teóricas, O Princípio Poético e A filosofia da composição, atentas ao se debruçarem sobre sua própria produção versificada. Sobre ele observou Charles Baudelaire, um inconteste admirador: "seu estilo é puro, adequado às idéias, dando delas a expressão exata. Poe é sempre correto. Fato bastante assinalável é que um homem de imaginação tão erradia e tão ambiciosa seja ao mesmo tempo tão amoroso das regras, e capaz de análises estudiosas e de pacientes pesquisas". ${ }^{1}$

Poe costuma ser distinguido pelos seus estudiosos como agudo explorador das exceções da alma humana; das exasperações que acometem o clima e tornam o ar brumoso, carregado, úmido ou solapado pelos ventos; assim como as alucinaçóes e quimeras que assaltam suas criaturas; ao lado de aspectos absurdos, histéricos ou descontrolados, colocando-as no intervalo entre a razão e a crise emotiva, mostrando-se atento à exploração emocional do homem nervoso. Emprega a primeira pessoa do singular como narrador com insistência, estando o tema do amor praticamente ausente de sua obra.

Todas essas características estão presentes na realização cênica de $O$ Coração Delator. O narrador - um assassino denunciado ao final pelas aceleradas batidas cardíacas - encontra-se em cena à entrada do público, recebendo sangue num aparato hospitalar e sentado numa cadeira de rodas. É o quanto basta para criar os signos maiores que regerão todo o espetáculo: o progresso da crise de nervos, a tentativa de dissimulação, a dor das lembranças, a taquicardia oriunda do pânico. Luzes discretas, um figurino sóbrio e um baú constituem a moldura espacial para deixar Renato Turnes livre para fazer vibrar as palavras. Tirando partido de sua voz grave, recorrendo à gesticulação essencial e dosando as inflexões num apurado diapasão soturno, um misto de auto-ironia e comiseração empurra seu desempenho na trilha minimal. O recurso final ao emprego de um coração real, pingando sangue, por ele retirado do baú, é destacado por um jato de luz, signo suficientemente grotesco para impactar a platéia.

Diversa, embora guardando características de espetáculo assemelhadas, é a vereda percorrida por Outsider. O que havia de minimalista na montagem anterior foi preterido em benefício do overacting: semi-nú, olheiras profundas, uma vela nas mãos e um livro onde aprendeu a ler, são os elementos mobilizados para infundir a qualidade essencial e mórbida, quase onírica, que o palco emana. Molhado (pois sai de uma tina cheia d'água), coberto por uma ampla capa, tateando as paredes cobertas

1 Charles Baudelaire, “Apresentação". In: Poemas e ensaios de Edgar Alan Poe. Porto Alegre: Globo, 1985, p. 16. 
de limbo, o narrador encontra seu momento de ápice ao término da escalada, ao adentrar o salão de festas que encima a torre. Todos fogem apavorados à sua presença e ele, desatento à sua condição, apenas se dá conta do grau de putrefação que o acomete ao deparar-se com um espelho. Em sua busca de si, o narrador percebese um duplo daquilo que foi.

Luzes e sombras bem ajustadas ajudam Outsider a adquirir seu tônus cênico; o espaço diminuto da sala e a proximidade estabelecida com o público igualmente são explorados, o que obriga o ator à tarefa de produzir minuciosa partitura para seu trabalho. Tais recursos percorrem as duas narrativas, conferindo às realizações não poucos traços simbolistas. Elemento comum às montagens é sua estruturação musical, uma vez que Jefferson é também regente e musicista, operando com pulsação muito própria o fluxo cênico.

Tal como ocorria naquela dramaturgia simbolista do final do século XIX, também aqui o espectador vai sendo introduzido aos poucos no cerne das angústias que enredam as criaturas. Isso faz com que a ação demore a se definir e haja larga exploração dos climas subjetivos, permitindo sejam verificadas minúcias de suas personalidades. Isso as torna seres especiais, conferindo-lhes um traçado alegórico ou, em certos casos, simbólico. A dicção poética soa natural nesse ambiente, e mesmo palavras excêntricas que vez por outra cruzam o espaço não perturbam a absorção da trama.

Do ponto de vista atorial, temos uma simbiose como resultante: a função primariamente épica de expor a diegese surge diluída, beneficiando a expressividade gestual, a exploração dos estados anímicos e as reações que os incidentes provocam no protagonista, tradicionalmente associadas ao dramático. Temos um narrador épico, mas não mais onisciente como em Brecht, porém dilacerado por dúvidas e cla- ros, imprecisões e errâncias, como em Heiner Müller, Koltés ou Novarina. Poder-se-ia pensar tal tipo de trabalho como neo-expressionista, se entendermos tal noção como ápice das melhores conquistas do absurdo, do teatro histérico de Foreman, da dissociação proposta por Kantor. Ou seja, vibrando em sintonia com a postura pós-dramática que caracteriza a cena contemporânea, na abrangente categoria proposta por Lehmann.

O público da Trilogia Lugosi é majoritariamente jovem, gótico, exibe piercings e correntes cruzando o corpo tatuado, fascinado em descobrir no palco uma projeção de si mesmo. Muitos nunca tinham ido ao teatro. Muitos nunca tinham ouvido falar em fantástico como espécime artístico, desatentos ao passado, quando moços imberbes matavam-se à leitura de Werther ou acabavam seus dias em meio à tuberculose, a sífilis ou a cirrose, mareados após o mergulho em paraísos artificiais. É essa comunicação estreita entre sala e palco o resultado mais palpável que a Trilogia está promovendo em Florianópolis, rastreando um público tido como perdido para o teatro.

Monólogos são almejados por atores e atrizes como oportunidades privilegiadas para esbanjar talento, contando-se às centenas nos últimos tempos. Em alguns casos são rebatizados como espetáculo-solo, em outros como performance, oferecendo, seja a que título for, uma oportunidade de contato vis-a-vis com intérpretes no auge de suas possibilidades.

Razão pela qual enfrentar um solo não é tarefa para principiantes, embora seja um projeto acalentado por muitos jovens. Não importa a direção artística para que se volte, não importa que recurso expressivo mobilize, um solo demanda, sobretudo, um momento interior pleno por parte do intérprete, capaz de transcendê-lo e empurrá-lo para além de si mesmo, projetando-se sobre a platéia. 